\title{
PENERAPAN MODEL PEMBELAJARAN PENEMUAN TERBIMBING UNTUK MENINGKATKAN HASIL BELAJAR SISWA PADA MATERI FUNGSI INVERS DI KELAS XI IPA 2 SMA NEGERI 9 PALU
}

\author{
Mariah Ulfa ${ }^{1)}$, Sudarman Bennu ${ }^{2)}$, Dasa Ismaimuza ${ }^{3)}$ \\ mariahulfasaad12@gmail.com ${ }^{l)}$, sudarmanbennu@gmail.com ${ }^{2}$, dasaismaimuza@yahoo.co.uk ${ }^{3)}$
}

\begin{abstract}
Abstrak: Tujuan penelitian ini adalah untuk mendeskripsikan penerapan model pembelajaran penemuan terbimbing dalam upaya meningkatkan hasil belajar siswa pada materi fungsi invers di kelas XI IPA 2 SMA Negeri 9 Palu. Jenis penelitian ini adalah penelitian tindakan kelas (PTK). Rumusan masalah dalam penelitian ini adalah Bagaimana penerapan model pembelajaran penemuan terbimbing dapat meningkatkan hasil belajar siswa pada materi Fungsi Invers Di kelas XI IPA 2 SMA Negeri 9 Palu. Rancangan penelitian ini mengacu pada desain penelitian Kemmis dan Mc. Taggart yakni (1) perencanaan, (2) pelaksanaan tindakan, (3) observasi dan (4) refleksi. Penelitian ini dilakukan dalam dua siklus. Hasil penelitian menunjukkan bahwa penerapan model penemuan terbimbing dapat meningkatkan hasil belajar siswa pada materi fungsi invers di kelas XI IPA 2 SMA Negeri 9 Palu mengikuti langkah-langkah Penemuan terbimbing yaitu (1) perumusan masalah,(2) pemprosesan data dan penyusunan konjektur, (3) pemeriksaan dan verbalisasi konjektur, dan (4) umpan balik. Jenis data yang digunakan adalah data kualitatif dan data kuantitatif dengan teknik pengumpulan data yaitu tes, observasi, catatan lapangan dan wawancara. Penelitian ini dilakukan dalam dua siklus. Hasil penelitian ini menunjukkan bahwa terjadi peningkatan hasil belajar siswa yang terlihat dari ketuntasan belajar klasikal siswa yang mengalami peningkatan dari siklus I ke siklus II, lembar hasil observasi aktivitas siswa dan guru kategori baik pada siklus I dan lembar hasil observasi aktivitas siswa kategori baik, lembar hasil observasi aktivitas guru kategori sangat baik pada siklus II. Berdasarkan hasil tersebut, dapat disimpulkan bahwa penerapan model pembelajaran penemuan terbimbing dapat meningkatkan hasil belajar siswa pada materi fungsi invers di kelas XI IPA2 SMA Negeri 9 Palu.
\end{abstract}

Kata Kunci : Model Pembelajaran Penemuan Terbimbing, Fungsi Invers.

Matematika merupakan salah satu ilmu yang berperan penting dalam kehidupan manusia. Pengetahuan yang dimiliki seseorang akan membawa pengaruh yang sangat besar dalam kehidupan masyarakat. Di dunia ini seseorang juga tidak terlepas dari aktivitas matematika. Dikehidupan sehari-hari banyak hal yang berkaitan erat dengan matematika, sebagai contoh saat melakukan kegiatan jual-beli, mengukur luas tanah, hingga memperkirakan banyaknya volume air dalam suatu wadah.

Matapelajaran matematika perlu diberikan kepada semua siswa mulai dari sekolah dasar untuk membekali mereka dengan kemampuan berpikir logis, analitis, sistematis, kritis dan kreatif serta kemampuan bekerja sama karena dengan belajar matematika, siswa akan belajar bernalar secara kritis, kreatif dan aktif. Sekaligus pada saat yang sama, siswa akan mengamati keberdayaan matematika (power of mathematics) dan tentunya menumbuh kembangkan kemampuan learning to learn. Kemampuan bernalar yang dipunyai siswa melalui proses belajar matematika itu akan meningkatkan pula kesiapannya untuk menjadi lifetime learner, dengan matematika ilmu mengalami perkembangan dari kualitatif ke kuantitatif, sehingga peran matematika sangat penting dalam perkembangan berbagai ilmu pengetahuan, karena matematika merupakan ilmu deduktif (Ba'diah: 2013)

Tujuan pendidikan matematika secara nasional tergambar mulai dari Sekolah Dasar sampai Sekolah Menengah, adapun beberapa tujuan pendidikan matematika sebagaimana tercantum dalam kurikulum 2006 yaitu : (1) menggunakan penalaran pada pola dan sifat, 
melakukan manipulasi matematika dalam membuat generalisasi, menyusun bukti, atau menjelaskan gagasan dan pernyataan matematika; (2) mengkomunikasikan gagasan dengan simbol, tabel, diagram atau media lain untuk memperjelas keadaan atau masalah (Depdiknas, 2006)

Proses pengajaran matematika diupayakan untuk tidak sekedar menyampaikan materi pembelajaran tetapi hendaknya melibatkan siswa secara aktif dalam proses pembelajaran. Siswa diharapkan akan dapat membangun pemahamannya sendiri. Guru dituntut untuk dapat menggunakan strategi, pendekatan atau metode yang dapat membantu siswa untuk mencapai tujuan pembelajaran yang telah ditetapkan.

Satu diantara materi yang dipelajari siswa di tingkat SMA adalah fungsi invers. Menurut Avika dan Suhito (2015) bahwa letak kesulitan belajar matematika peserta didik kelas XI IPS 1 SMA Negeri 1 Bobotsari pada tahun pelajaran 2013/2014 di materi komposisi fungsi dan invers fungsi adalah (1) pemahaman prosedur menentukan fungsi pembentuk kedua yang lemah, (2) keterampilan dasar aritmetika dan pemahaman bentuk aljabar yang lemah, (3) kekacauan manipulasi aljabar untuk menentukan invers fungsi, (4) pemahaman dasar tentang syarat-syarat fungsi komposisi dan fungsi invers yang tidak memadai

Sejalan dengan penelitian yang dilakukan oleh Rahayu yang mengatakan bahwa pembelajaran matematika dengan materi Fungsi komposisi dan invers termasuk materi abstrak sehingga siswa mengalami kesulitan dalam memahami dan menyelesaikan permasalahan. Hal ini terbukti dengan hasil belajar individual siswa belum mencapai kriteria ketuntasan minimal yaitu 73 pada Tahun Ajaran 2012-2013.

Pada materi fungsi komposisi dan invers pada siswa SMAN 2 Mranggen, kelas XI-IPS-1.

Sehubungan dengan beberapa penelitian tersebut peneliti melakukan wawancara dengan guru matematika kelas XI SMA Negeri 9 Palu pada tanggal 11 November 2016, diperoleh informasi bahwa sebagian besar siswa mengalami kesulitan pada materi komposisi fungsi dan fungsi invers, khususnya tentang fungsi invers. Dialog dengan guru matematika tersebut juga mengungkapkan bahwa pada saat mengajarkan materi tentang fungsi invers, sebagian besar siswa bisa mengerjakan soal yang diberikan, namun apabila ditanyakan keesokan harinya, banyak siswa yang sudah lupa. Informasi lain yang diperoleh peneliti dari dialog tersebut adalah guru sudah berusaha menerapkan berbagai model maupun metode pembelajaran dalam mengajarkan materi fungsi invers dalam rangka meningkatkan hasil belajar siswa, seperti model pembelajaran langsung, metode ceramah,namun tetap juga diperoleh hasil belajar siswa yang rendah.

Berkaitan dengan hasil wawancara dengan guru matematika di SMA Negeri 9 Palu, peneliti melakukan tes identifikasi masalah pada tanggal 2 Februari 2017 kepada siswa kelas XII IPA 2. Soal yang peneliti sajikan pada tes identifikasi masalah yaitu, sebagai berikut : Tentukan invers dari fungsi berikut: 1). $f(x)=2 \mathrm{x}-5 ., 2) f(x)=\frac{1}{2 x}$., 3). $f(x)=$ $\frac{2}{2 x-4}$. 4) $f(x)=\frac{4 x-2}{x+3}$.

Berdasarkan hasil tes yang diberikan diperoleh informasi dari beberapa siswa yang melakukan kesalahan dalam menyelesaiakan soal tentang fungsi invers. Jawaban siswa yang memiliki tingkat kemiripan kesalahan di masing-masing soal dapat dilihat pada gambar 1 dan gambar 2 berikut: 


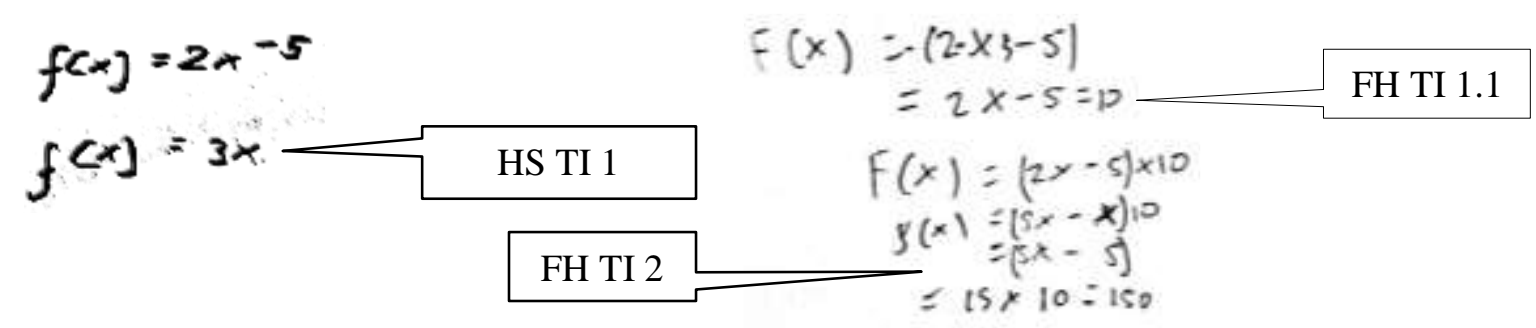

Gambar 1: Jawaban Siswa HS soal nomor 1 pada tes identifikasi
Gambar 2: Jawaban Siswa FH soal nomor 1 pada tes identifikasi

Hasil yang diperoleh untuk soal nomor 1 dapat menunjukkan bahwa siswa HS dan FH tidak dapat menentukan rumus fungsi invers dari fungsi yang diberikan pada soal. Gambar 1 menunjukkan hasil pekerjaan siswa HS yang tidak jelas menuliskan dari mana asal jawaban tersebut diperoleh. Hasil pekerjaan siswa HS jelas tidak dapat menunjukkan rumus fungsi invers, karena siswa HS langsung saja menuliskan hasil pekerjaannya yaitu $f(x)=3 x$ sebagaimana ditunjukkan pada kode HS TI 1, seharusnya dikerjakan sesuai dengan langkah-langkan dalam menentukan rumus fungsi invers. Hal ini menyebabkan jawaban akhir siswa salah.

Gambar 2 menunjukkan bahwa siswa FH salah dalam menentukan rumus fungsi invers. Terlihat bahwa FH melakukan kesalahan operasi hitung aljabar dalam menetukan rumus fungsi invers, hal ini menyebabkan jawaban akhir siswa salah seperti ditunukkan sebagaimana ditunjukkan pada kode SY TI 2 FH TI 2. Hasil analisis lebih lanjut terhadap jawaban siswa untuk soal nomor 1 yaitu dari 19 siswa yang mengikuti tes identifikasi masalah, 4 orang menjawab seperti jawaban siswa HS, 4 orangmenjawab seperti jawaban siswa $\mathrm{FH}$, dan 10 orang tidak menjawab.

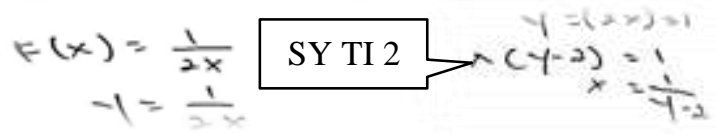

Gambar 3: Jawaban Siswa SY soal nomor 2 pada tes identifikasi

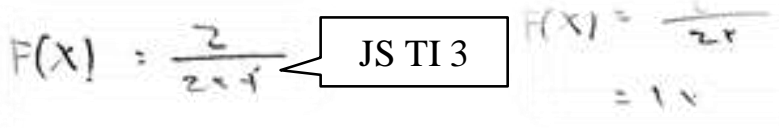

Gambar 4: Jawaban Siswa JS Soal Nomor 3 pada tes identifikasi

Berdasarkan Gambar 3, dapat disimpulkan bahwa dalam menentukan rumus fungsi invers, siswa melakukan kesalahan prosedur seperti terlihat pada gambar, pada langkah ke4 siswa SY menjawab $x(y-2)=1$ seharusnya $x(2 y)=1$ sebagaimana ditunjukkan pada kode SY TI 2. Hal ini menyebabkan jawaban akhir siswa salah. Kesalahan berikutnya yang dapat diamati dari jawaban siswa adalah siswa belum mampu menentukan rumus fungsi invers dan siswa juga melakukan kesalahan operasi hitung aljabar. Kesalahan-kesalahan tersebut mengakibatkan jawaban siswa menjadi salah. Hasil analisis jawaban siswa di atas, dapat diketahui bahwa siswa pada dasarnya belum mengetahui langkah-langkah yang harus ditempuh dalam menyelesaikan soal tersebut dan masih mengalami kesalahan dalam penulisan dan perhitungan pengerjaan serta kesalahan prosedural. Hasil analisis lebih lanjut terhadap jawaban siswa untuk soal nomor 2 yaitu dari 19 siswa yang mengikuti tes identifikasi masalah, 3 orang menjawab benar, 4 orang menjawab seperti jawaban siswa SY, dan 8 orang tidak menjawab.

Selanjutnya, Gambar 4 menunjukkan bahwa siswa belum mampu memahami permintaan soal dengan baik, kekeliruan siswa pada Gambar 4 yaitu pada langkah pertama 
siswa JS menghilangkan angka 4 pada penyebut dan pada langkah kedua siswa membagi $\frac{2}{2 x}$ menjadi $1 x$, seharusnya siswa mengerjakan soal sesuai prosedur sebagaimana ditunjukkan pada kode JS TI 3. Hal ini menunjukan bahwa siswa belum mampu menjawab soal sesuai dengan permintaan. Namun, bila diperhatikan lebih lanjut hasil pekerjaan siswa menunjukan bahwa siswa keliru saat menentukan rumus fungsi invers.

Hasil analisis lebih lanjut terhadap jawaban siswa untuk soal nomor 3 yaitu dari 19 siswa yang mengikuti tes identifikasi masalah, 4 orang menjawab seperti jawaban siswa siswa JS, dan 15 orang tidak menjawab.

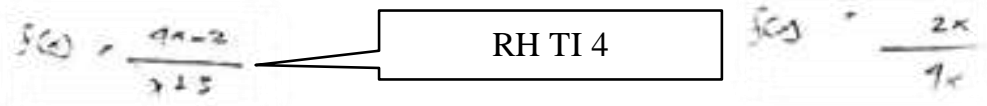

Gambar 5: Jawaban Siswa RH soal nomor 4 pada tes identifikasi

Analisis Gambar 5 menunjukkan hasil pekerjaan siswa soal nomor empat, terlihat bahwa siswa RH menuliskan $4 x$ sebagai penyebut dan mengilangkan $\mathrm{x}+3$ sebagai penyebut. Selain itu, siwa juga belum mampu melanjutkan proses penyelesaiaan sebagaimana diminta oleh soal. Jumlah siswa pada kesalahan tipe ini sebanyak 7 orang.

Berdasarkan jawaban dari soal tes identifikasi yang diberikan kepada siswa kelas XII IPA 2 ditemukan bahwa kesalahan yang banyak dilakukan siswa adalah kesalahan operasi hitung aljabar, tidak memahami permintaan soal dan tidak menjawab soal sesuai prosedur. Peneliti berasumsi bahwa permasalahan tersebut disebabkan karena siswa tidak memiliki pemahaman konseptual dan keterampilan dalam menyelesaikan soal pada materi fungsi invers. Hasil wawancara peneliti dengan beberapa siswa, diperoleh informasi bahwa menurut siswa pelajaran matematika adalah pelajaran yang sangat sulit. Dan materi fungsi invers merupakan materi yang sudah tidak diingat lagi karena materinya kurang menarik. Informasi lain yang diperoleh bahwa dalam mempelajari materi fungsi invers, guru menjelaskan sekilas materinya, memberikan contoh, kemudian memberikan soal untuk dikerjakan siswa. Hal ini memberikan gambaran tentang proses pembelajaran yang berpusat pada guru (teacher centered), bukan berpusat pada siswa (student centered). Pembelajaran seperti ini menyebabkan siswa cenderung pasif tanpa mengkonstruksi sendiri pemahamannya.

Upaya yang dapat dilakukan untuk mengatasi permasalahan tentang pembelajaran yang berpusat pada guru adalah dengan menerapkan suatu pembelajaran yang memberi kesempatan seluas-luasnya kepada siswa untuk mengkonstruksi sendiri pengetahuan yang harus dimiliki. Proses pembelajaran harus dirancang agar memberi kesempatan kepada siswa dalam melakukan penyelidikan, penemuan, dan membuat kesimpulan sendiri terhadap konsep yang dipelajari. Tujuannya yaitu agar pengetahuan yang diperoleh siswa dapt bertahan lama, karena siswa sendiri yang turut andil dalam menemukan pengetahuan baru tersebut berdasarkan pengalaman dan pengetahuan yang telah mereka miliki sebelumnya. Oleh karena itu, peneliti tertarik untuk menerapkan suatu cara yang mengajak siswa untuk mengkonstruksi pengetahuan baru secara mandiri sehingga proses pembelajaran menjadi lebih berkesan dan bermakna Inayah (2013:7).

Alternatif pembelajaran yang dapat membimbing siswa membangun pemahamannya sendiri, yaitu dengan menerapkan metode penemuan terbimbing. Pada metode penemuan terbimbing siswa didorong untuk berpikir sendiri dalam menemukan prinsip umum berdasarkan bahan atau data yang disediakan oleh guru .Peran guru hanya bertindak sebagai fasilitator dan membimbing siswa seperlunya. Siswa didorong untuk berfikir sendiri sehingga dapat menemukan prinsip umum berdasarkan bahan atau data yang telah disediakan guru. Metode ini mempunyai keunggulan antara lain siswa dapat berpartisipasi aktif dalam pembelajaran, menumbuhkan sekaligus menanamkan sikap inquiry, 
mendukung kemampuan problem solving siswa dan menjadikan pengetahuan yang diperoleh lebih lama membekas dalam ingatan siswakarena mereka dilibatkan langsung dalam menemukannya, kusumadewi dalam Badjeber $(2011,4)$.

Beberapa penelitian yang telah dilakukan dengan menggunakan metode penemuan terbimbing yang membuktikan bahwa melalui metode penemuan terbimbing dapat mengatasi masalah siswa dalam belajar matematika dan dapat meningkatkan hasil belajar siswa, yaitu penelitian yang dilakukan Barakati (2017:80) mengemukakan bahwa model pembelajaran penemuan terbimbing dapat meningkatkan kemampuan siswa kelas VIII C SMP Negeri 11 Palu dalam menemukan luas permukaan prisma dengan mengikuti tahaptahap model pembelajaran penemuan terbimbing.

Hasil penelitian Muhaimin (2018:85) dengan menggunakan metode penemuan terbimbing di kelas XII Keperawatan SMK Negeri 4 Palu dapat meningkatkan hasil belajar siswa pada materi integral tak tentu fungsi aljabar dengan menggunakan langkah-langkah yaitu pada kegiatan awal, guru menyampaikan tujuan pembelajaran yang hendak dicapai sehingga dapat mengarahkan siswa dan mengingatkan materi prasyarat. Kegiatan inti, peneliti mengikuti sebagai berikut :1)perumusan masalah, peneliti menyajikan masalah yang akan diselesaikan siswa yaitu materi tentang integral tak tentu fungsil aljabar, lalu peneliti membagikan LKPD penemuan terbimbing kepada setiap kelompok, 2) pemprosesan data dan penyusunan dugaan, siswa memproses dan menganalisis data yang terdapat di dalam LKPD dan peneliti memberikan bimbingan sejauh yang diperlukan dan siswa menyusun konjektur atau prakiraan dari hasil analisis yang dilakukan, 3) pemeriksaan konjektur dan verbalisasi dugaan, peneliti memeriksa konjektur yang telah dibuat oleh siswa. Hal ini penting dilakukan untuk meyakinkan kebenaran prakiraan siswa, sehingga menuju arah yang hendak dicapai, 4) umpan balik (feed back), peneliti memberikan soal latihan tambahan dan menyimpulkan bersama materi yang telah dipelajari. Kegiatan penutup, guru memberikan Pekerjaan Rumah (PR) sebagai latihan siswa di luar sekolah dan menutup pembelajaran.

Hubungan antara penelitian di atas dengan penelitian yang akan dilakukan oleh peneliti adalah penggunan model pembelajaran penemuan terbimbing yang dapat meningkatkan hasil belajar siswa.

Berdasarkan uraian di atas, peneliti melakukan penelitian tentang "Penerapan Model Pembelajaran Penemuan Terbimbing untuk Meningkatkan Hasil Belajar Siswa pada Materi Fungsi Invers di Kelas XI IPA 2 SMA Negeri 9 Palu"

\section{METODE PENELITIAN}

Jenis penelitian ini adalah penelitian tindakan kelas. Desain penelitian ini mengacu pada model penelitian tindakan kelas yang dikembangkan oleh Stephen Kemmis dan Robbin McTaggart yang merupakan pengembangan dari model Kurt Lewin (Taniredja, 2010 : 24) yang terdiri terdiri dari empat komponen yaitu perencanaan, tindakan, pengamatan, dan refleksi. Tindakan dan pengamatan dilaksanakan pada satu waktu yang sama. Subjek penelitian ini adalah seluruh siswa kelas XI IPA 2 di SMA Negeri 9 Palu yang terdaftar pada tahun ajaran 2016/2017 dengan banyaknya siswa adalah 25 orang siswa. Pemilihan subjek berdasarkan saran dari guru bidang studi di sekolah tersebut. Pada penelitian dipilih 3 orang informan untuk keperluan wawancara dengan kualifikasi kemampuan yang berbeda (berkemampuan tinggi, sedang, dan rendah) berdasarkan hasil tes awal dan hasil konsultasi dengan guru matematika di sekolah tersebut. 
Jenis data dalam penelitian ini yaitu data kualitatif dan data kuantitatif. Teknik pengumpulan data yang digunakan dalam penelitian ini adalah observasi, wawancara, catatan lapangan, dan tes tertulis. Tes tertulis yang digunakan terbagi menjadi dua yaitu tes pra tindakan dan tes akhir tindakan. Analisis data dilakukan dengan mengacu pada analisis data kualitatif model Miles dan Huberman (Sugiyono, 2010 : 337), yaitu data reduction (reduksi data), data display (penyajian data), dan conclusion drawing (penarikan kesimpulan). Penelitian ini dikatakan berhasil dilihat dari aktivitas guru (peneliti) dalam mengelola pembelajaran di kelas dan aktivitas siswa selama mengikuti pembelajaran dengan menggunakan model pembelajaran penemuan terbimbing serta hasil belajar siswa. Kualitas aktivitas guru dan aktivitas siswa dalam proses pembelajaran dinyatakan berhasil apabila kualitas proses pembelajaran untuk setiap aspek yang dinilai berada dalam kategori baik atau sangat baik. Hasil belajar siswa setelah mengikuti pembelajaran dengan metode penemuan terbimbing dikatakan berhasil apabila memenuhi indikator keberhasilan penelitian pada siklus I yaitu siswa mampu menentukan syarat agar suatu fungsi mempunyai invers dan siswa dapat menyebutkan sifat-sifat fungsi invers. Adapun indikator keberhasilan untuk siklus II yaitu siswa mampu menentukan rumus fungsi invers dari suatu fungsi sesuai dengan prosedur. Suatu kelas dikatakan tuntas belajar secara klasikal apabila ketuntasan belajar klasikal lebih atau sama dengan $75 \%$.

\section{HASIL PENELITIAN}

Hasil penelitian ini terdiri atas hasil pelaksanaan pra tindakan dan hasil pelaksanaan tindakan. Sebelum pelaksanaan tindakan dilakukan, terlebih dahulu peneliti memberikan tes awal kepada siswa. Tujuan diberikannya tes awal yaitu untuk mengetahui tingkat pemahaman siswa terhadap materi prasyarat dari materi fungsi invers. Selain untuk mengetahui kemampuan siswa pada materi prasyarat, tes awal juga bertujuan untuk pembentukkan kelompok belajar yang heterogen dan sebagai pedoman untuk menentukan informan penelitian. Hasil analisis tes awal menunjukkan bahwa pemahaman siswa mengenai materi prasyarat yang diberikan masih cukup rendah.

Pelaksanaan tindakan pada penelitian ini terdiri dari dua siklus, yaitu siklus I dan siklus II. Setiap siklus dilaksanakan dalam dua kali pertemuan. Pertemuan pertama siklus I membahas mengenai syarat agar suatu fungsi memiliki invers, sedangkan pada siklus II membahas mengenai materi menentukan rumus fungsi invers. Pada pertemuan kedua siklus I dan siklus II, peneliti memberikan tes akhir tindakan. Pelaksanaan pembelajaran yang dilakukan meliputi kegiatan pendahuluan, kegiatan inti, dan kegiatan akhir. Kegiatan awal didahului oleh peneliti dengan menyampaikan tujuan dan memotivasi siswa dan menyajikan informasi serta mengorganisasikan siswa ke dalam kelompok belajar. Kemudian, kegiatan inti meliputi langkah perumusan masalah, pemprosesan data dan penyusunan konjektur, pemeriksaan dan verbalisasi konjektur, dan umpan balik. Selanjutnya, kegiatan akhir meliputi penutup yaitu menyampaikan pembelajaran pertemuan berikutnya.

Kegiatan pendahuluan pada pembelajaran siklus I dan siklus II yaitu guru mengawali pembelajaran dengan mengucapkan salam, menyapa siswa dalam kelas, meminta ketua kelas untuk memimpin teman-temannya berdoa. Setelah berdo'a guru mengabsen siswa. Siswa yang hadir pada pertemuan pertama ada 24 siswa, dan 1 siswa tidak hadir tanpa keterangan. Selanjutnya guru mempersiapkan siswa untuk belajar dengan meminta siswa untuk menyiapkan buku dan alat tulis mereka. Guru menyampaikan tujuan pembelajaran yang akan dicapai yaitu siswa dapat memahami syarat agar suatu fungsi memiliki invers. Kemudian guru memotivasi siswa. Guru menjelaskan kepada siswa bahwa 
cara belajar yang akan dilakukan adalah secara berkelompok, dan setiap kelompok akan dibagikan LKS yang didalamnya terdapat prosedur kerja dan pertanyaan-pertanyaan yang akan menuntun siswa menemukan syarat agar suatu fungsi memiliki invers. Sebelum membagi kelompok guru menjelaskan materi prasayarat yaitu materi pembagian fungsi aljabar sebagaimana pada hasil tes awal bahwa ada 16 siswa yang keliru dalam menjawab soal tes awal khususnya pada materi pembagian fungsi aljabar. Setelah penjelasan singkat tersebut, guru menampilkan nama-nama tiap kelompok dan meminta siswa untuk segera bergabung dengan kelompoknya masing-masing, masing-masing untuk siklus I dan siklus II.

Kegiatan inti pembelajaran siklus I dan siklus II dilakukan dengan menerapkan langkah perumusan masalah, yaitu guru memberikan informasi tentang kegiatan yang akan dilakukan siswa selama proses pembelajaran. Guru menjelaskan bahwa setiap siswa harus bertanggung jawab terhadap kelompoknya. Oleh karena itu, semua siswa dalam kelompok harus berpartisipasi dan bekerja sama dalam mengerjakan LKS yang akan dibagikan, karena setelah mengerjakan LKS, guru akan meminta perwakilan dari masing-masing kelompok untuk mempresentasekan hasil kerja kelompoknya

Selanjutnya, langkah pemprosesan data dan penyusunan konjektur diawali dengan guru meminta siswa untuk mengikuti prosedur kerja dan menjawab pertanyaan-pertanyaan dalam LKS. Guru juga menjelaskan agar setiap siswa dalam kelompok mau bekerja sama dan saling bertukar pikiran dalam mengerjakan LKS. Pada saat siswa mengerjakan LKS, guru mengawasi dan memberikan bimbingan kepada siswa apabila terdapat hal-hal yang kurang jelas dan tidak dimengerti selama proses penemuan. Guru betindak sebagai fasilitator dan motivator yang bertugas untuk mengamati, memotivasi, dan mengarahkan siswa untuk menemukan syarat agar suatu fungsi memiliki invers. Pada saat siswa mengerjakan LKS, guru mengontrol jalannya diskusi tiap kelompok. Guru memberikan bimbingan kepada kelompok yang mengalami kesulitan. Pada tahap ini, guru juga memberikan kesempatan kepada siswa untuk menanyakan hal-hal yang kurang atau belum dipahami.

Selama diskusi kelompok berlangsung, siswa telah berani untuk menanyakan hal-hal yang belum dipahaminya kepada guru. Sehingga guru memberikan bimbingan kepada siswa. Pemberian yang dimaksud untuk mengarahkan siswa dalam menyelesaikan kesulitan yang dialaminya. Dalam artian guru tidak memberitahu jawaban sebenarnya secara langsung. Satu diantara lima kelompok yang bertanya kepada guru adalah kelompok I, yaitu siswa HB. Oleh karena itu, guru memberi bimbingan. Setelah diberikan bimbingan, HB pun mengerti dan melanjutkan mengerjakan LKS. Selanjutnya, guru kembali mengamati aktivitas siswa dalam kelompok.

Selanjutnya, kegiatan pada langkah pemeriksaan dan verbalisasi konjektur yaitu peneliti sebagai guru mengamati dan memeriksa LKS mereka. Pemeriksaan yang dilakukan oleh guru dimulai dari kelompok yang pertama mengacungkan tangan pertanda bahwa semua LKS berhasil mereka kerjakan. Guru memanggil perwakilan siswa dari masing-masing kelompok untuk mempresentasekan hasil temuan mereka. Kelompok II dan III memperoleh kesempatan untuk menuliskan hasil temuan mereka di papan tulis. Hal ini disebabkan karena siswa dalam kelompok II, III dan berani mengacungkan tangan saat guru menanyakan kelompok mana yang berani mempresentasekan hasil kerjanya. Adapun kelompok I, VI dan V diberi kesempatan untuk menanggapi hasil temuan kelompok lain. Namun, diantara kelompok I, VI dan V. Setelah kegiatan presentase selesai, guru bersama-sama dengan siswa menyimpulkan materi yang telah dipelajari berdasarkan hasil diskusi siswa pada saat mengerjakan LKS.

Kegiatan pada langkah umpan balik yaitu setelah siswa menyimpulkan materi yang baru saja dipelajari, guru memberikan 3 nomor soal latihan tambahan kepada siswa yang berkaitan dengan syarat agar suatu fungsi memiliki invers. Soal yang diberikan ditulis di 
papan tulis. Hal ini dilakukan untuk mencegah siswa melihat pekerjaan siswa lain. Guru juga mengingatkan kepada siswa agar dalam mengerjakan soal, sebaiknya menuliskan yang diketahui dan ditanyakan dari soal.

Kegiatan akhir pembelajaran di setiap siklus yaitu kegiatan penutup, pada kegiatan ini guru menginformasikan kepada siswa bahwa pertemuan selanjutnya akan diadakan tes tentang materi syarat agar suatu fungsi memiliki invers. Guru berpesan kepada siswa agar kembali mempelajari materi syarat agar suatu fungsi memiliki invers di rumah. Akhirnya, guru menutup pembelajaran dengan meminta salah satu siswa memimpin temannya untuk berdoa sebelum keluar ruangan. Setelah berdoa, guru mengucapkan salam.

Pertemuan kedua untuk setiap siklus yaitu pemberian tes akhir tindakan kepada siswa kelas XI IPA 2 SMA Negeri 9 Palu. Soal yang diberikan pada siklus I sebanyak 4 nomor. Satu diantara bagian soal yang diberikan yaitu : Diketahui $f: \mathrm{R} \rightarrow \mathrm{R}$ dengan ketentuan $f(x)=3 \mathrm{x}+8$. Tentukan $f^{-1}(x)$. Jawaban MZ dan NS pada tes akhir tindakan siklus I dapat dilihat pada Gambar berikut.

$$
\begin{array}{rlrl}
f(x) & =3 x+8 & f(y) & =\frac{y-8}{3} \\
y & =3 x+8 & f(x) & =\frac{x-8}{3} \\
-3 x & =8-y & f^{-1}(x)=\frac{y-8}{3} \\
3 x & =y-8 & \\
x=\frac{y-8}{3} &
\end{array}
$$

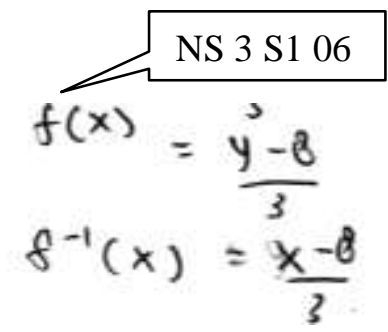

Gambar 7 Jawaban siswa NS

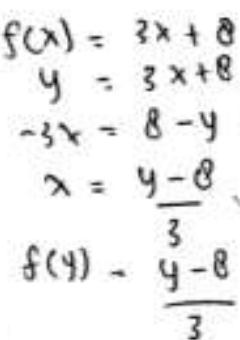

Gambar 6 Jawaban siswa MZ

Berdasarakan Gambar 6, diperoleh informasi bahwa siswa MZ dapat menentukan invers dari fungsi dengan benar. Soal yang diberikan sebanyak 3 butir soal, semua jawaban MZ benar. Hal ini menunjukkan bahwa MT mampu memahami soal dengan baik dan mengetahui syarat suatu fungsi agar memiliki invers dari soal tes tersebut. Siswa NS keliru menjawab soal pada langkah ke 6 yang seharusnya $f(x)=\frac{x-8}{3}$, NS menjawab $f(x)=\frac{y-8}{3}$ sebagaimana ditunjukkan pada kode NS 3 S1 06

Soal yang diberikan pada siklus II sebanyak 2 nomor. Satu diantara bagian soal yang diberikan yaitu tentukan fungsi invers dari $f(x)=\frac{3 x+4}{2 x-1}$. Jawaban MZ dan NS pada tes akhir tindakan siklus II dapat dilihat pada Gambar berikut:

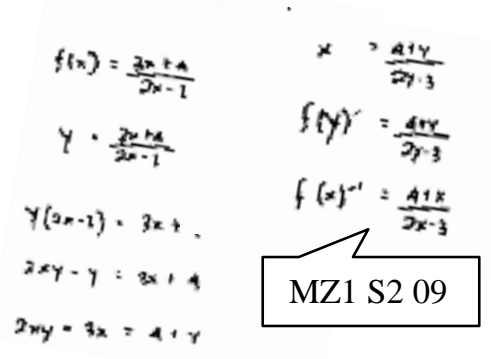

Gambar 8 Jawaban siswa MZ
1). $f(x)=\frac{3 x+1}{2 x-1}$

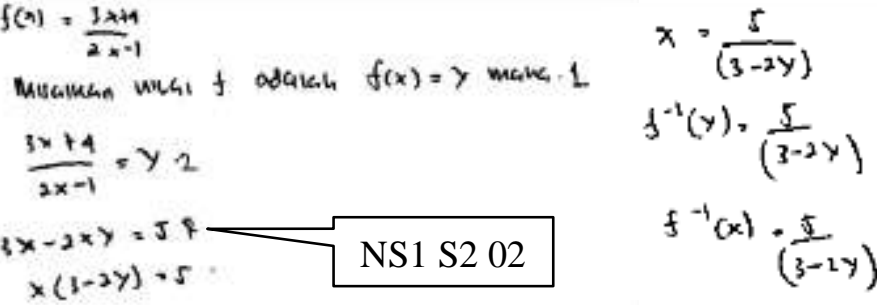

Berdasarkan Gambar 8 dan 9, diperoleh informasi bahwa siswa MZ dapat menentukan invers dari suatu fungsi yaitu fungsi $f(x)=\frac{3 x+4}{2 x-1}$ memiliki invers $f^{-1}=\frac{x+4}{2 x-3}$, 
MZ menjawab dengan benar, MZ menjawab fungsi $f(x)=\frac{3 x+4}{2 x-1}$ sebagaimana ditunjukkan pada kode MZ1 S2 09. Siswa NS belum dapat menentukan invers dari suatu fungsi yaitu fungsi $f(x)=\frac{3 x+4}{2 x-1}$, NS menjawab keliru, NS menjawab fungsi $f(x)=\frac{3 x+4}{2 x-1}$ sebagaimana ditunjukkan pada kode NS1 S2 06. NS menjawab keliru mulai dari langkah ke 2 sebagaimana ditunjukkan pada kode NS1 S2 02 sampai langkah terakhir.

Observasi dilakukan dengan mengamati setiap aspek dalam lembar observasi aktivitas guru maupun aktivitas siswa. Aspek-aspek aktivitas peneliti sebagai guru yang diamati selama pembelajaran berlangsung menggunakan lembar observasi meliputi: (1) guru memberikan data-data yang diperlukan sehubungan dengan materi yang diajarkan, (2) guru menjelaskan hal-hal yang akan dilakukan dengan bantuan LKS sesuai dengan materi yang dipelajari, (3) guru memberikan bimbingan seperlunya kepada siswa, (4) guru mengamati siswa dalam kelompok pada saat menyusun konjektur, (5) guru memeriksa hasil konjektur siswa , (6) guru memberikan alasan terhadap konjektur siswa yang salah, (7) guru memberikan kesempatan kepada siswa untuk menyusun kembali konjektur yang keliru, (8) guru memilih perwakilan siswa dari masing-masing kelompok untuk mengungkapkan dan menuliskan konjektur yang benar, (9) guru memberikan kesempatan pada setiap kelompok untuk menanggapi dan mengajukan pertanyaan apabila masih ada hal-hal yang belum jelas, (10) guru membimbing siswa untuk membuat kesimpulan, (11) guru memberikan soal latihan tambahan yang berkaitan dengan materi pembelajaran, (12) guru menyampaikan kegiatan yang akan dilakukan pada pertemuan selanjutnya.

Aspek yang dinilai yaitu penilaian baik yang diberikan oleh pengamat terdiri dari 6 aspek dari 12 aspek penilaian yaitu terdapat pada aspek guru menjelaskan hal-hal yang akan dilakukan dengan bantuan LKS, guru memberikan kesempatan kepada siswa untuk menyusun kembali konjektur yang keliru, guru memilih perwakilat siswa dari masing-masing kelompok untuk mengungkapkan dan menuliskan konjektur yang benar, guru memberikan kesempatan pada setiap kelompok untuk menanggapi dan mengajukan pertanyaan apabila masih ada hal-hal yang belum jelas, guru memberikan bimbingan seperlunya kepada siswa yang mengalami kesulitan dalam menyelesaikan soal yang disajikan.

Penilaian cukup yang diberikan oleh pengamat yaitu terdiri dari 12 aspek dari 13 aspek penilaian yaitu terdapat pada aspek guru memberikan data-data yang diperlukan sehubungan dengan materi yang diajarkan, guru memberikan bimbingan seperlunya kepada siswa, guru mengamati siswa dalam kelompok pada saat menyusun konjektur, guru memeriksa hasil konjektur siswa, guru memberikan alasan terhadap konjektur siswa yang salah, guru memberikan soal latihan tambahan yang berkaitan dengan materi pembelajaran, guru menyampaikan kegiatan yang akan dilakukan pada pertemuan selanjutnya.

Aspek-aspek aktivitas siswa yang diamati selama pembelajaran berlangsung menggunakan lembar observasi meliputi: adalah (1) Siswa menyususn, memproses, mengorganisir, dan menganalisis data yang diberikan guru, (2) siswa mengerjakan hal-hal yang akan dilakukan dengan bantuan LKS sesuai dengan materi yang akan dipelajari, (3) siswa memperbaiki konjektur yang yang salah berdasarkan bimbingan guru, (4) siswa mengungkapkan dan menuliskan konjektur di depan kelas, (5) siswa menyimpulkan materi yang baru saja dipelajari dengan bimbingan guru, (6) siswa mengerjakan soal latihan tambahan yang diberikan guru secara individu.

Hasil observasi yang dinilai yaitu penilaian sangat baik yang diberikan oleh pengamat yaitu terdiri dari 2 aspek dari 6 aspek penilaian yaitu terdapat pada aspek siswa menyimpulkan materi yang baru saja dipelajari dengan bimbingan guru, siswa mengerjakan soal latihan tambahan yang diberikan guru secara individu. Penilaian baik yang diberikan 
oleh pengamat yaitu terdiri dari 3 aspek dari 6 aspek penilaian yaitu terdapat pada aspek adalah siswa menyususn, memproses, mengorganisir, dan menganalisis data yang diberikan guru, siswa mengerjakan hal-hal yang akan dilakukan dengan bantuan LKS sesuai dengan materi yang akan dipelajari, siswa mengungkapkan dan menuliskan konjektur di depan kelas. Penilaian cukup yang diberikan oleh pengamat yaitu terdiri dari 1 aspek dari 6 aspek penilaian yaitu terdapat pada aspek siswa memperbaiki konjektur yang yang salah berdasarkan bimbingan guru

\section{PEMBAHASAN}

Penelitian yang dilakukan merupakan penelitian tindakan kelas (PTK) yang bertujuan mendeskripsikan penerapan model pembelajaran penemuan terbmbing untuk meningkatkan hasil belajar siswa pada materi fungsi invers di kelas XI IPA 2 SMA Negeri 9 Palu dengan jumlah siswa adalah 25 orang siswa. Penelitian ini dilakukan melalui dua siklus. Setiap siklus terdiri atas 4 komponen, yaitu (1) perencanaan, (2) pelaksanaan tindakan, (3) observasi, dan (4) refleksi. Hal ini sesuai dengan yang dikemukakan oleh Kemmis dan Mc. Taggart (Arikunto, 2013:16). Sebelum pelaksanaan tindakan, guru terlebih dahulu memberikan tes awal kepada siswa untuk mengetahui kemampuan siswa pada materi prasyarat. Hal ini sesuai dengan pendapat Sutrisno (2012: 212) yang menyatakan bahwa pelaksanaan tes sebelum perlakuan dilakukan untuk mengetahui pemahaman awal siswa. Materi pada tes awal adalah fungsi aljabar yang merupakan materi prasyarat fungsi invers.

Kegiatan awal pembelajaran dilakukan dengan peneliti terlebih dahulu membuka pelajaran dengan mengucapkan salam, menyapa siswa, mengajak siswa untuk berdoa dan mengecek kehadiran siswa, serta mempersiapkan siswa untuk belajar baik merespon maupun menerima atau menolak materi yang diberikan. Hal ini sesuai dengan hukum kesiapan Gintings (2008) yang menjelaskan tentang adanya hubungan antara kesiapan seseorang dalam merespon, menerima atau menolak terhadap stimulan yang diberikan. Mempersiapkan siswa untuk belajar memang perlu untuk dilakukan agar siswa siap dalam belajar. Selanjutnya, peneliti memberikan apersepsi kepada siswa tentang pembelajaran sebelumnya. Sejalan dengan pendapat Rohani (2004) bahwa apersepsi disajikan melalui pertanyaan untuk mengetahui apakah siswa masih ingat atau lupa, sudah menguasai atau belum tentang suatu materi dah hasilnya dijadikan acuan untuk memulai pengajaran yang baru. Kemudian peneliti menyampaikan tujuan pembelajaran yang ingin dicapai yaitu untuk menentukan invers dari suatu fungsi dan memberikan motivasi kepada siswa sehingga siswa bersemangat dalam mengikuti pembeljaran. Hal ini sesuai dengan pendapat Barlian (2013) yang menyatakan bahwa penyampaian tujuan pembelajaran dilakukan agar siswa mengetahui dan berusaha mencapai tujuan pembelajaran yang diinginkan.

Pelaksanaan Pembelajaran siklus I dan siklus II dilakukan dengan menerapkan model pembelajaran penemuan terbimbing dimulai dengan langkah perumusan masalah, kemudian langkah pengumpulan data dan pemrosesan data, setelah itu langkah pemeriksaan konjektur dan verbalisasi konjektur, dan terakhir adalah langkah umpan balik. Tahap-tahap pembelajaran penemuan terbimbing ini sesuai dengan pendapat Widdiarto dalam Padhalisa (2009:9).

Langkah perumusan masalah dilakukan dengan peneliti memberikan LKS kepada setiap kelompok yang bertujuan untuk menuntun dan mendorong siswa dalam proses penemuan serta dapat mengembangkan kreativitas siswa dalam belajar, sehingga dapat menuntun siswa menarik kesimpulan materi fungsi invers. Hal ini sejalan dengan pendapat Trianto (2009:22) bahwa LKS adalah panduan siswa yang digunakan untuk melakukan penyelidikan atau pemecahan masalah. 
Langkah pengumpulan data dan pemrosesan data dilakukan dengan peneliti meminta masing-masing kelompok mengamati LKS serta mendiskusikannya. Kemudian siswa mengerjakan langkah-langkah yang terdapat pada LKS. Setelah itu siswa berdiskusi dalam menemukan syarat agar suatu fungsi memiliki invers. Selama siswa mengerjakan LKS, peneliti mengawasi dan memberikan bimbingan kepada siswa apabila terdapat hal-hal yang kurang jelas dan tidak dimengerti selama proses penemuan. Peneliti bertindak sebagai fasilitator dan motivator yang bertugas untuk mengamati, memotivasi, dan mengarahkan siswa untuk menemukan invers dari suatu fungsi, Ini dilakukan agar setiap siswa yang bermasalah dalam menyelesaikan LKS dapat secepatnya diberikan bimbingan. Hal ini sesuai dengan pendapat Nusantara dan Syafi'i (2013) yang menyatakan bahwa seorang guru memiliki kewajiban dalam mengatasi kesulitan yang dialami siswa pada proses belajarnya dengan melakukan upaya pemberian bantuan seminimal mungkin dikenal dengan istilah scaffolding.

Langkah pemeriksaan konjektur dan verbalisasi konjektur dilakukan dengan peneliti meminta perwakilan dari masing-masing kelompok untuk mempresentasekan hasil temuan mereka, dan kelompok lain memberikan tanggapan. Hal ini sejalan dengan Rahmawati (2013) yang menyatakan bahwa perlunya pembiasaan untuk memberikan tanggapan terhadap jawaban yang diberikan orang lain dalam pembelajaran matematika, sehingga yang dipelajari siswa menjadi lebih bermakna.

Setelah konjektur atau dugaan sementara berhasil disusun oleh setiap kelompok, peneliti bersama-sama dengan siswa menyimpulkan materi yang telah dipelajari. Kesimpulan yang diperoleh bahwa untuk menentukan invers dari suatu fungsi maka fungsi tersebut merupakan fungsi bijektif.

Selanjutnya pada langkah umpan balik, peneliti meminta untuk masing-masing siswa mengerjakan soal latihan tambahan yang berkaitan dengan materi. Berdasarkan jawaban mereka terhadap soal tersebut, diperoleh informasi bahwa sebagian siswa sudah paham pengaplikasian prinsip yang mereka temukan untuk menyelesaikan soal. Namun, sebagiannya lagi belum. Oleh karena itu, setelah semua siswa selesai mengerjakan soal latihan yang diberikan, guru kembali mengerjakan soal latihan tersebut di papan tulis. Hal ini didukung oleh pendapat Trianto (2011: 38) yang menyatakan bahwa guru dapat menggunakan berbagai cara untuk memberikan umpan balik secara lisan, tes dan komentar tertulis. Tanpa umpan balik spesifik, siswa tak mungkin dapat memperbaiki kekurangannya dan tidak dapat mencapai tingkat penguasaan keterampilan yang mantap. Setelah itu pada kegiatan penutup, peneliti menginformasikan kegiatan pembelajaran yang akan dilakukan pada pertemuan berikutnya. Kemudian peneliti mengakhiri pembelajaran dengan mengucapkan salam. Hasil tes akhir tindakan siklus I terlihat bahwa sebagian besar siswa masih menimbulkan kesalahan dalam menentukan syarat agar suatu fungsi memiliki invers.

Kegiatan pada pertemuan selanjutnya yaitu peneliti memberikan tes akhir tindakan kepada setiap siswa. Berdasarkan hasil tes akhir tindakan siklus I diperoleh informasi bahwa siswa yang mengikuti tes belum mampu menentukan syarat agar suatu fungsi memiliki invers. Siswa masih menimbukan kesalahan dalam menentukan syarat agar suatu fungsi memiliki invers. Kesalahan-kesalahan lain yaitu siswa salah dalam melakukan perhitungan dan salah opersi hitung aljabar.

Setelah kegiatan pembelajaran siklus I berakhir, peneliti bersama dengan guru matematika melakukan refleksi terhadap seluruh kegiatan pembelajaran yang dilakukan. Refleksi ini dilakukan untuk mengetahui kekurangan yang terjadi pada pelaksanaan siklus I dan rekomendasi kegiatan perbaikan pada siklus II berikutnya. Hal ini sesuai dengan pernyataan Arikunto (2007:16) bahwa refleksi adalah kegiatan menganalisis data yang telah diperoleh berdasarkan tes awal yang dilakukan sebelum kegiatan pembelajaran 
berlangsung, hasil tes akhir tindakan yang dilakukan sesudah tindakan pembelajaran, hasil observasi, catatan lapangan, dan hasil wawancara sebagai dasar perbaikan rencana siklus berikutnya jika masih dibutuhkan.

Setelah melakukan observasi, hasil observasi guru mengalami peningkatan dari siklus I ke siklus II yaitu peneliti sudah fokus kepada siswa, peneliti membimbing siswa seperlunya, dan menurut pengamat peneliti sudah membimbing dan mengarahkan siswa dengan tenang. Peneliti juga telah memenuhi indikator keberhasilan guru. Hasil observasi siswa juga mengalami peningkatan dari siklus I ke siklus II yaitu pada awalnya siswa sudah antusias menjawab apersepsi yang diberikan guru tentang syarat agar suatu fungsi memiliki invers. Siswa juga sudah tenang pada saat pembagian kelompok. Siswa juga memikirkan pemecahan masalah yang diberikan secara bersama-sama. Semua siswa dari yang berkemampuan tinggi, sedang, rendah turut andil dalam pemecahan masalah. Hal ini sejalan dengan penelitian yang dilakukan oleh Sari dan Jatmiko (2014) yang mengemukakan bahwa aktivitas pada proses pembelajaran penemuan terbimbing siswa mengalami peningkatan, siswa lebih aktif dan lebih berani mengemukakan pendapatnya. Siswa juga telah memenuhi indikator keberhasilan siswa.

Hasil dari analisis dan pembahasan yang telah diuraikan dapat disimpulkan bahwa penerapan model pembelajaran penemuan terbimbing dengan mengikuti langkah-langkah yaitu perumusan masalah, pemprosesan data dan penyusunan konjektur, pemeriksaan dan verbalisasi konjektur, dan umpan balik dapat meningkatkan Hasil Belajar siswa kelas XI IPA 2 SMA Negeri 9 Palu dalam menentukan invers dari suatu fungsi.

\section{KESIMPULAN}

Berdasarkan hasil penelitian dan pembahasan, maka dapat disimpulkan bahwa penerapan model pembelajaran penemuan terbimbing dalam kegiatan pembelajaran pada materi fungsi invers dapat meningkatkan hasil belajar siswa kelas XI IPA 2 SMA Negeri 9 Palu, dengan menerapkan keempat langkah model pembelajaran penemuan terbimbing sebagai berikut: (1) perumusan masalah, (2) pemrosesan data dan penyusunan konjektur, (3) pemeriksaan dugaan sementara dan verbalisasi dugaan sementara, dan (4) umpan balik. Adapun hasil pengamatan aktivitas guru dalam mengelolah pembelajaran yaitu pada siklus I kategori baik dan siklus II kategori sangat baik. Hasil pengamatan aktivitas siswa dalam mengelolah pembelajaran yaitu pada siklus I kategori baik dan siklus II kategori sangat baik. Hasil tes akhir tindakan siswa kelas XI IPA 2 SMA Negeri 9 Palu setelah mengikuti pembelajaran dengan model pembelajaran penemuan terbimbing yaitu pada siklus I presentase siswa yang tuntas sebesar $64 \%$ dan pada siklus II presentase siswa yang tuntas sebesar $76 \%$.

Penerapan model pembelajaran penemuan terbimbing yang dapat meningkatkan hasil belajar siswa tentang materi fungsi invers di kelas XI IPA 2 SMA Negeri 9 Palu ditempuh dengan cara guru memberikan apersepsi kepada siswa tentang syarat-syarat agar suatu fugsi memiliki invers; menyampaikan tujuan pembelajaran dan merumuskan masalah dengan jelas, membagikan LKS kepada setiap kelompok dalam rangka menemukan invers dari suatu fungsi; mengawasi jalannya proses penemuan yang dilakukan oleh siswa; memeriksa dugaan sementara yang telah dibuat oleh siswa; mempersilahkan siswa untuk mempresentasekan hasil penemuannya; bersama-sama dengan siswa menyimpulkan materi yang telah dipelajari, dan memberikan soal latihan tambahan yang berkaitan dengan materi invers yang telah dipelajari secara individu. 


\section{SARAN}

Berdasarkan kesimpulsm di atas, maka beberapa saran yang dapat peneliti berikan yaitu bagi guru, Pembelajaran matematika melalui penerapan metode penemuan terbimbing dengan menggunakan LKS dapat digunakan sebagai salah satu alternatif untuk meningkatkan hasil belajar siswa khususnya pada materi fungsi invers. Bagi Siswa, dalam pembelajaran matematika yang menerapkan metode penemuan terbimbing, hendaknya memperhatikan waktu pembelajaran dengan baik dan menghargai orang lain agar pembelajaran dapat berlangsung dengan lebih baik. Bagi peneliti selanjutnya, hendaknya dapat mencoba menerapkan metode penemuan terbimbing untuk mengetahui efektivitas model pembelajaran ini dalam meningkatkan hasil belajar siswa pada materi matematika.

\section{DAFTAR PUSTAKA}

Arikunto, S. (2007). Prosedur Penelitian Suatu Pendekatan Praktik. Jakarta: Rineka Cipta

Badjeber,R. (2011). Penerapan Metode penemuan terbimbing untuk meningkatkan hasil belajar siswa kelas VII Ki Hajar Dewantoro SMP Negeri 4 Palu pada materi hubungan antar sudut. Skripsi Sarjana FKIP Universitas Tadulako Palu: tidak diterbitkan.

Barakati, F. (2017). Penerapan Model pembelajaran penemuan terbimbing untuk meningkatkan kemampuan siswa kelas VIII C SMP Negeri 11 Palu dalam menemukan luas permukaan prisma. Skripsi Sarjana FKIP Universitas Tadulako Palu: tidak diterbitkan.

Barlian, Ikbal. (2013). Begitu Pentingkah Strategi Belajar Mengajar Bagi Guru?. Dalam Jurnal Forum Sosial [Online]. Vol. 6 (1), 6 halaman. Tersedia http:// eprints.unsri .ac.id/2268/2/isi.pdf [17 Desember 2018].

Ba'diah, U. (2013). Pentingnya Pendidikan Matematika. [Online]. Tersedia :http:// media. kompasiana.com/new-media/2013/07/02/pentingnya-pendidikan-matematika-573 871.html [25 Februari 2018].

Depdiknas. (2006). Kurikulum Tingkat Satuan Pendidikan (KTSP) 2006 Mata Pelajaran Matematika. Departemen Pendidikan Nasional

Gintings, A. (2008). Esensi Praktis Belajar dan Pembelajaran. Bandung: Humaniora

Inayah, N. (2013). Penerapan Metode Penemuan Terbimbing Untuk Meningkatkan Hasil Belajar Siswa Kelas VIIIc SMP Negeri 13 Palu Pada Materi Hubungan Sudut Pusat, Panjang Busur, Dan Luas Juring Lingkaran. Skripsi Sarjana FKIP Universitas Tadulako Palu: tidak diterbitkan.

Kemmis, S dan Mc. Taggart, R. (2013). The Action Research Planner: Doing Critical Participatory Action Research. Singapura:Springer Sience[Online]. Tersedia:https: //books.google.co.id/books?id=GB3BAAAQBAJ\&printsec=frontcover\&dq=kemmis +mctaggart\&hl=en\&sa=X\&redir_esc $=\mathrm{y} \# \mathrm{v}=$ onepage $\& \mathrm{q}=$ kemmis\%20and $\%$ mctaggart $\& \mathrm{f}=$ false.[23 Januari 2018].

Muhaimin, Sukayasa, Sudarman Bennu. (2018). "Penerapan Metode Penemuan Terbimbing Untuk Meningkatkan Hasil Belajar Pada Materi Integral Tak Tentu Fungsi Alajabar Siswa Kelas XII Keperawatan SMK Negeri 4 Palu“.jurnal Elektronik 
Pendidikan Matematika Tadulako [Online], Volume 5 Nomor 4, Juni 2018. Tersedia http://jurnal.untad.ac.id. [5 Mei 2019]

Nusantara, Toto dan Safi'i, Imam. (2013). Diagnosis Kesalahan Siswa Pada Materi

Faktorisasi Bentuk Aljabar dan Scaffoldingnya. [Online]. Jurnal Pendidikan matematika UM. Tersedia: http://jurnal-online.um.ac.id /data/artikel/artikel 298877 56D901C2029476E E329D179594.pdf [17 Desember 2018].

Padhalisa. (2009). Meningkatkan Hasil Belajar Siswa Melalui Metode Penemuan Terbimbing pada Materi Keliling dan Luas Segitiga di Kelas VII F SMP Negeri 2 Palu. Skripsi Sarjana FKIP Universitas Tadulako Palu: tidak diterbitkan.

Rahayu, T. (2013) "Pembelajaran Matematika Berbantuan Miniatur Teenzania Untuk Meningkatkan Karakter Dan Kemampuan Berpikir Kreatif”. Journal of Primary Educational. [Online], 2 (2). 100. Tersedia: http:// journal. unnes.ac.id/sju/index. php/jpe. [16 Januari 2017]

Rohani, A. (2004). Pengelolaan Pengajaran. Jakarta: Rineka Cipta.

Sugiyono. (2010). Metode Penelitian Kuantitatif, Kualitatif, dan R\&D. Bandung: CV Alfabeta

Sutrisno (2012.) Efektivitas Pembelajaran dengan Metode Penemuan Terbimbing terhadap Pemahaman Konsep Matematis Siswa. Jurnal Pendidikan Matematika. [online], Volume 1, Nomor 4, Nopember 2012, tersedia: http://fkip.unila.ac.id/ojs/data/journals /11/JPMUVol1No4/016_Sutrisno.pdf,diaksespadatanggal 16 Januari 2017.

Trianto, (2009). Mendesain Model PembelajaranInovatif-Progresif. Surabaya: Kencana Prenada Media Group

Widdiharto, Rachmadi. 2004. Model-model Pembelajaran Matematika SMP. Yogyakarta: Depdiknas. 